\title{
Focused verbal inflections in Spanish
}

\section{Carlos Muñoz Pérez}

Pontifical Catholic University of Chile

carlos.munozperez@uc.cl

Matías Verdecchia

IIF/SADAF/CONICET - University of Buenos Aires

mnverdecchia@filo.uba.ar

Received: 24-03-2021

Accepted: 06-04-2021

Published: 07-04-2021

How to cite: Muñoz Pérez, Carlos and Matías Verdecchia. 2021. Focused verbal inflections in Spanish. Isogloss. Open Journal of Romance Linguistics 7, 5:1-4. DOI: https://doi.org/10.5565/rev/isogloss.141

We would like to draw attention on some previously unnoticed contrasts involving contrastive foci and null subjects in Spanish. Take the answer by speaker B in (1), which involves contrastive focus on the pronominal subject.

(1) A: Yocociné la cena anoche.

(Spanish)

I cooked.1sG the dinner last.night

'I cooked dinner yesterday.'

B: NOSOTROS cocinamos la cena anoche. we cooked.1PL the dinner last.night 'WE cooked dinner last night.'

Spanish can express a contrast similar to (1B) by omitting the subject and accenting the finite verb, e.g., (2B). We refer to this phenomenon as inflectional focus (IF), as what seems to be contrasted in this case are the Person and Number features in the verbal inflection. 

A: Cociné la cena anoche. cooked.1SG the dinner last.night 'I cooked dinner last night.'
B: COCINAMOS la cena anoche. cooked.1PL the dinner last.night 'WE cooked dinner last night.'

IF is very productive in Spanish (e.g., the Communist Bugs Bunny series of memes exploits it constantly), although its distribution is limited to the contrasts 1SG-1PL, 1SG-2PL and 2SG-1PL. Third person verbs can only be contrasted in antiagreement contexts, which involve a lexical DP as subject (Ordóñez 1997, Saab 2008).

(3) A: Los estudiantes compraron libros nuevos.

the students bought.3PL books new

'The students bought new books.'

B: Los estudiantes COMPRAMOS libros nuevos.

the students bought.1PL books new

'WE students bought new books.'

While they look similar at first, the focus phenomena in (1B) and (2B) display non-trivial differences. To begin with, IF requires formal contrast on the focused element, i.e., the phonological representation of the accented verb needs to be distinct to that of its counterpart in the antecedent sentence, e.g., (4); the remaining constituents must remain identical to their antecedents, e.g., (5).

(4) A: Cociné la cena anoche.

cooked.1SG the dinner last.night

'I cooked dinner last night.'

B: \# COCINÉ la cena anoche. cooked.1SG the dinner last.night

'I cooked dinner last night.'

(5) A: Hablamos con Eliana ayer. talked.1PL with Eliana yesterday

'We talked to Eliana yesterday.'

B: HABLÉ con \#ella/Eliana ayer.

talked.1SG with she Eliana yesterday

'I talked to her/Eliana yesterday.'

As can be seen in (6B), neither of these requirements holds for focused pronominal subjects. 


A: Yo hablé con Eliana ayer.
I talked.1SG with Eliana yesterday
'I talked to Eliana yesterday.'
B: YO hablé con ella ayer.
I talked.1SG with she yesterday
'I talked to her yesterday.'

These differences suggest that IF pertains to the domain of expression focus (Krifka 2008), i.e., foci that evoke alternatives to a linguistic expression based on its form and not on its denotation. Under such analysis, the answer in (2B) is to be analyzed as in rejection of the (singular) form cocine 'I cooked' in favor of the (plural) form cocinamos 'we cooked'. The switch in reference of the null subject from $1 \mathrm{SG}$ to $1 \mathrm{PL}$ should be taken to be a by-product of this metalinguistic correction.

The phenomenon, however, displays interpretive restrictions that go beyond this first characterization. IF can either extend or shrink the set of referents of the null subject in the antecedent sentence, but cannot completely deny the proposition expressed by it. Take the examples in (1) and (2). The pronoun nosotros 'we' in (1B) is ambiguous between an inclusive and an exclusive interpretation; under the latter, A did not cook the dinner at all. In (2B), however, the inclusive interpretation is mandatory; it must be the case that A did some of the cooking, i.e., (2A) is not entirely false.

This restriction is at play in (7). Since speaker B is not part of the set referred to by the null subject in (7A), IF becomes unacceptable in this context.

A: $\quad[\text { Ana y yo }]_{i}$ teníamos sueño. Por eso cocinamos $s_{i}$ la cena Ana and I had.1PL dream by that cooked.1PL the dinner temprano. early.

'Ana and I were sleepy. That's why we cooked dinner early.'

B: \# COCINÉ la cena temprano. cooked.1SG the dinner early. 'I cooked the dinner early, (not you people).'

It is unclear to us how to account for this property. We conjecture that it might follow from the interaction of expression focus and principles of anaphora resolution for null subjects. Further research is necessary to provide a concrete explanation.

\section{References}

Krifka, Manfred. 2008. Basic notions of information structure. Acta Linguistica Hungarica 55(3-4): 243-276.

https://doi.org/10.1556/ALing.55.2008.3-4.2 
Ordóñez, Francisco. 1997. Word order and clause structure in Spanish and other Romance Languages. New York: NYU dissertation.

Saab, Andrés. 2008. Hacia una teoría de la identidad parcial en la elipsis. Buenos Aires: Universidad de Buenos Aires dissertation. 